(ㄱ Дріянська В.Е., Дудар І.О., Шіфріс І.М., Савченко В.С., Калініна Н.А., Холод В.В., 2021

doi:10.37321/immunology.2021.1-2-05

удК 616.61-036.1-002.2-06:616.381-089.819

\title{
ОСОБЛИВОСТІ СИРОВАТКОВИХ РІВНІВ ІЛ-10 У ХВОРИХ НА ХРОНІЧНУ ХВОРОБУ НИРОК, ЯКІ ЛІКУЮТЬСЯ З ВИКОРИСТАННЯМ ДІАЛІЗНИХ МЕТОДІВ
}

\author{
ДРІЯНСЬКА В.Е., ДУДАР І.О., ШІФРІС І.М., САВЧЕНКО В.С., \\ КАЛІНІНА Н.А., ХОЛОД В.В.
}

ДУ «ннститут нефрології НАМН України», Київ, Україна

Існує ряд регуляторних механізмів, що забезпечують тонкий баланс між ефективною імунною відповіддю і патогенезом та перебігом патології. Один із таких механізмів обумовлений протизапальним інтерлейкіном-10 (ІЛ-10), який є членом сімейства цитокінів, що включає також ІЛ-19 -22, $-24,-26,-28 \mathrm{~A},-28 \mathrm{~B}$ і -29. Всі цитокіни цього сімейства мають схожі риси геномної організації, зв'язуються $з$ подібними рецепторами та активуються шляхом JAK/STAT (Janus kinase/signal transducer and activator of transcription) $[4,5]$.

Участь ІЛ-10 у багатьох патологічних станах продемонстрована як на моделях тварин, так і на людях з мутаціями в IЛ-10/IЛ-10R [6]. Однак, незважаючи на значний прогрес в біології ІЛ-10, все ще існує безліч невирішених питань. Основні його функції протизапальні та інгібуючі, він $€$ регулятором негативного зворотного зв'язку, який впливає на запалення через аутокринні і паракринні механізми $[6,25]$.

Цей імуносупресивний ефект є широким і проявляється як на клітинному, так і на гуморальному рівнях, хоча є два домінуючих напрямки, за допомогою яких ІЛ-10 обмежує потенційно руйнівні запальні реакції: 1) інгібування презентації антигену дендритними клітинами і 2) інгібування активації і інфільтрації макрофагів з вторинним ефектом ослаблення експресії прозапальних цитокінів. [7]. Вважається, що на клітинному рівні ІЛ-10 діє як посттранскрипційний регуляторний агент для пригнічення білка, стабілізуючого інформаційну РНК (мРНК) HuR (людського антигену R), сприяючи специфічній дестабілізації MPHК запальних цитокінів. Вважається, що IL-10 інгібує апоптотичні сигнальні шляхи, а саме - p38 MAPK (мітоген-активована протеїнкіназа), через STAT3 (сигнальний перетворювач і активатор транскрипції 3) залежну передачу сигналів, тим самим обмежуючи загибель тканин і дисфункцію органів після травми. [14].

ІЛ-10 грає важливу регулюючу роль уздоров'ї і гомеостазі як на місцевому, так і на системному рівнях, він є складним багатофункціональним цитокіном, який безпосередньо бере участь у фіброзній реакції на пошкодження [27], що при подальших дослідженнях може дати більш точну картину його ефектів, специфічних для клітин і навколишніх умов, а також дозволить визначи- ти його терапевтичний потенціал, в тому числі у хворих на XXH.

Важливе значення мають отримані дані щодо ролі ІЛ-10 та його взаємодій з прозапальною ланкою імунітету у разі різних патологій, в тому числі ниркових та коморбідних захворювань у пацієнтів з XXH [2, 10, 13, 21].

Останнім часом значна увага приділяється імунним механізмам в розвитку хронічної ниркової недостатності (ХНH). ХНН характеризується прогресуючим фіброзом клубочків і втратою функції нефрону внаслідок гломерулярного склерозу і атрофії канальців, незалежно від етіології захворювань нирок.

ХНН розвивається в результаті хронічних гломерулонефриту (ХГН) та пієлонефриту, діабетичного гломерулосклерозу та інших захворювань, які вражають нирки [18]. ХГН - прогресуюче запальне захворювання нирок, характеризується незворотним і прогресуючим клубочковим і тубулоінтерстиціальним фіброзом [3, 17]. Механізми, за допомогою яких запальний процес призводить до погіршення ниркової функції, до кінця не з'ясовані. Відомо, що імунозапальні медіатори модулюють ендотеліальну функцію, адгезію та інтерстиціальну міграцію циркулюючих імунних клітин (моноцитів, лейкоцитів або нейтрофілів) [28]. ІЛ-10 може сприяти відкладенню імунних комплексів в мезангії, тим самим сприяє прогресуванню пошкодження клубочків [11, 23].

Імунологічні порушення, які запускають реакції цитокінового каскаду, сприяють етіології та патогенезу ХНН. На тлі цього, ІЛ-10 грає важливу роль в регуляції і підтримці нормальної функції нирок, а також при гострому ураженні нирок і в прогресуванні XXН. У нирках IЛ-10 секретується, головним чином, мезангіальними і ендотеліальними клітинами. Мезангіальні клітини є основним локальним джерелом ІЛ-10 в нормальній нирці.

Корисні властивості ІЛ-10 були ідентифіковані при множинних гетерогенних патологіях нирок, а також негативно впливали на ураження клубочків [8, 11]. Mu et al. повідомили, що ІЛ10 знижує фіброз на щурячій моделі хронічного захворювання нирок (CKD), що пояснюють його імуносупресивною функцією [17]. Продемон- 
стровано серйозне пошкодження канальців 3 посиленням запалення і відкладення колагену у мишей з дефіцитом IЛ-10, у них також підвищена регуляція профібротичного маркеру - -SMA $[9,12]$. ІЛ-10 впливає на шляхи передачі сигналів профіброзу, які є унікальними для нирок - ІЛ10 вивільняється мезенхімальними стромальними клітинами, пригнічує передачу сигналів RAAS i, таким чином, зменшує рубцювання канальців після односторонньої обструкції сечоводу (UUO) [9]. Молекулярний механізм цього полягає в зниженні МРНК запальних цитокінів через пригнічення транскрипції HuR. Введення екзогенного ІЛ-10 після UUO послаблює тубулоінтерстиціальний фіброз аналогічно ефектам ІЛ-10, які спостерігаються в шкірі [25].

У хворих з хронічною нирковою недостатністю на початкових етапах іiї розвитку продукція ІЛ-10 вище, ніж в групі здорових осіб, але дані щодо цього цитокіну у діалізних хворих не співпадають у різних авторів [24]. Якщо після пересадки нирки в післяопераційному періоді рівень ІЛ-10 виявляється низьким, це $\epsilon$ фактором розвитку реакції відторгнення, а при його високій продукції відзначається толерантність до трансплантату. У хворих з кризом відторгнення часто спостерігається зниження здатності лімфоцитів продукувати ІЛ-10 [16].

Гемотрансфузії, які актуальні для хворих на XXH, збільшують продукцію ІЛ-10. При лікуванні гепатиту C (який часто супроводжує діалізних хворих) інтерфероном високий рівень ІЛ-10, поряд з низьким вихідним рівнем ГГТ (гама-глютаматтранспептідази) і нормальним рівнем заліза, розглядають як один з основних критеріїв сприятливого терапевтичного прогнозу. Низькі рівні цього інтерлейкіна асоціюють $з$ метаболічним синдромом у пацієнтів [22, 25].

Протизапальні цитокіни, які відіграють істотну роль в підтримці балансу про- і протизапальних факторів, впливають на перебіг ішемічної хвороби серця і її ускладнень як найбільш частої коморбідної патології у хворих на XXH VД, тому що ІЛ-10 є одним з основних інгібіторів синтезу прозапальних цитокінів макрофагами, що гальмує надмірний ріст ендотелію.

З огляду на широкий спектр протизапальних властивостей ІЛ-10, терапевтичні маніпуляції з цим цитокіном викликали великий інтерес [15, $19,20]$. Введення ІЛ-10 в різних моделях коліту у тварин довело свою ефективність; були зроблені зусилля по розробці стратегій для специфічної доставки ІЛ-10, і цікавим підходом була розробка бактерій, сконструйованих для транспортування протизапального цитокіну в кишківник [22].

Терапевтичні маніпуляції з ІЛ-10 були передбачені в контексті кількох інших патологій. I при ревматоїдному артриті, і при псоріазі введення ІЛ-10 дало деякі багатообіцяючі резуль- тати на доклінічному та клінічному рівнях [22]. При алергічній астмі, коли патологічні реакції на алергени розвиваються через порушення імунної толерантності, успішні терапевтичні стратегії пов'язані з підвищенням рівня ІЛ-10. Важка стероїдорезистентна астма асоціюється 3 нездатністю клітин пацієнта підвищувати рівень ІЛ-10 у відповідь на дексаметазон [29].

Протилежна стратегія полягає в блокаді ІЛ10 при патологіях, коли його надлишок шкідливий. Невелике клінічне випробування, проведене у пацієнтів на системний червоний вовчак, показало поліпшення симптомів після блокади ІЛ-10 [6].

Таким чином, надлишкова і генералізована продукція прозапальних цитокінів призводить до розвитку органних дисфункцій. Такі цитокіни як інтерлейкін-6 (ІЛ-6), інтерлейкін-8 (ІЛ-8) і фактор некрозу пухлини-альфа (ФНП- ), є медіаторами запалення, які відіграють важливу роль у патогенезі ХНН. Інтерлейкін-10 (ІЛ-10) має імуномодулюючі властивості і пригнічує запальні процеси [17, 23, 26], що дуже важливо характеризувати разом з прозапальною ланкою, визначаючи ступінь дисбалансу у пацієнтів з XXН УД.

Розуміння складних сигнальних механізмів за участю ІЛ-10 може розкрити нові потенційні терапевтичні цілі, в тому числі у хворих на XXH, які лікуються за допомогою гемо- (ГД) чи перитонеального (ПД) діалізу.

Метою роботи було визначити середні сироваткові рівні ІЛ-10 у хворих на ХХH VД і особливості у разі використання ГД- (1 гр. - 41 хворий) та ПД-лікування (2 гр. - 14 хворих).

Матеріали і методи. Особливості сироваткових рівнів ІЛ-10 визначали у 55 пацієнтів з XXH VД, що лікувалися за допомогою діалізних методів - гемо- (ГД) та перитонеального (ПД) діалізу протягом 2015-2019 рр. Дослідження проводили за допомогою імуноферментного аналізатору «SunRise TouchScreen», використовували тест-системи „Вектор Бест” (РФ). Межі нормальних значень (референтний діапазон) були отримані на основі результатів дослідження 20 умовно здорових осіб.

Отримані дані оброблені статистично на персональному комп'ютері за допомогою пакета програм "SPSS for Windows. Версія 11" та "MedStat". Для статистичної обробки використовувались параметричні критерії статистики тест Ст'юдента або непараметричні - критерій Уілкоксона. Достовірною вважали різницю при $p<0,05$. Кореляційний зв'язок кількісних показників рівнів цитокінів, за умов їх нормального розподілу, визначали за методом Пірсона (r). Кореляційний аналіз за Кендалом ( ) використовували у разі відсутності нормального розподілу показників. 
Отримані результати. Дослідження ІЛ-10 показали тенденцію до зниження середніх показників протизапального цитокіну у всіх хворих на XXН VД порівняно із здоровими - відповідно, $23,4(15,6 ; 109,4)$ та $97,7(31,3 ; 143,2)$ пг/мл $(p=0,059)$.

Середній рівень ІЛ-10 у ПД-хворих достовірно нижче норми, тоді як у ГД - спостерігалась тенденція до зниження порівняно зі здоровими (рис. 1). При цьому не відмічено достовірних відмінностей за середніми показниками ІЛ-10 залежно від модальності терапії - $p=0,255$. Такі результати частково підтверджують результати Малишева Н.Є. та ін. про те, що дисбаланс у хворих на XXН з прогресуючим перебігом обумовлений активацією клітин, що продукують прозапальні цитокіни, на тлі незміненої секреції протизапальних, в тому числі ІЛ-10 [1].

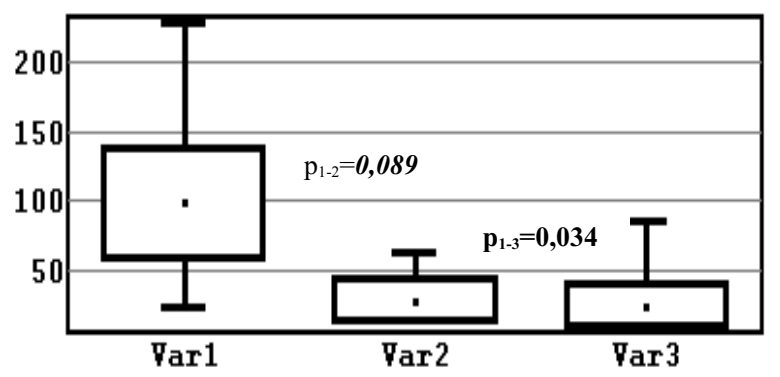

Рис. 1 - Середні рівні ІЛ-10 у ГД і ПД-пацієнтів (відповідно, Var 2 і 3) в порівнянні з показниками у здорових донорів (Var 1).

В процесі лікування не виявлено достовірної динаміки ІЛ-10 як у ГД-, так і ПД-хворих (рис. 2), хоча після сеансів еферентної терапії середні рівні цього протизапального медіатора не відрізнялись від норми в обох групах ( $p=0,199$ i $\mathrm{p}=0,100)$.

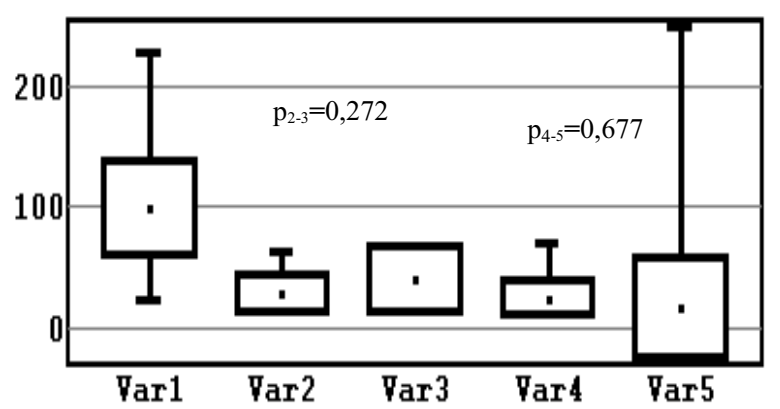

Рис. 2 - Середні рівні ІЛ-10 у ГД (Var 2 і 3) і ПДпацієнтів (Var 4 і 5) до та після проведеного лікування і у здорових донорів (Var 1).

Проведений аналіз кореляційних зв'язків (коефіцієнт Кендала) між прозапальними цитокінами (ФНП-, ІЛ-6, -8, МСР-1), та протизапальним ІЛ-10 у хворих обох груп.
У ГД-хворих виявлено прямий кореляційний зв'язок між ІЛ-6 та ІЛ-8 (Тau=0,224, $\mathrm{p}=0,03$ ) та зворотній між ІЛ-6 ті ІЛ-10 (Таu=-0,271, p=0,01). Наші результати співпадають 3 даними інших дослідників і їх думкою про важливу роль ІЛ-6 в індукції секреції ІЛ-8 і навпаки, а також його зв'язків із протизапальним ІЛ-10 [1]. У ПДпацієнтів існує зворотній зв'язок між ІЛ-8 та ІЛ$10(\mathrm{Tau}=-0,556)$ на рівні значущості $(\mathrm{p}=0,01)$.

\section{ВИСНОВКИ}

Діалізна терапія у хворих на XXH супроводжується зниженням рівнів ІЛ-10 (більш вираженим у ПД-пацієнтів) на фоні тривалої дії високої активності клітин імунної системи по продукції прозапальних цитокінів і, відповідно, хронічного запалення зі зниженням компенсаторних можливостей Т-регуляторних лімфоцитів по секреції у відповідь на цей стан протизапального медіатора.

Лікування з використанням ПД призводить до більш негативного впливу на баланс взаємодії клітин моноцитарно-макрофагальної системи і Т-регуляторними, про що свідчить наявність кореляційних прямих зв'язків у ГД-хворих між ІЛ-6 та ІЛ-8 $(p=0,03)$ та зворотній між ІЛ-6 ті ІЛ-10 ( $p=0,01)$, тоді як у ПД - лише зворотній між ІЛ-8 та ІЛ-10 ( $p=0,01)$.

Конфлікт інтересів: автори заявляють про відсутність конфлікту інтересів.

\section{PЕЗЮME}

\section{ОСОБЛИВОСТІ СИРОВАТКОВИХ РІВНІВ ІЛ-10 У ХВОРИХ НА ХРОНІЧНУ ХВОРОБУ НИРОК, ЯКІ ЛІКУЮТЬСЯ З ВИКОРИСТАННЯМ ДІАЛІЗНИХ МЕТОДІВ}

Дріянська В.Е., Дудар І.О., Шіфріс І.М., Савченко В.С., Калініна Н.А., Холод В.В.

дУ «Інститут нефрології НАМН України», Київ, Україна

Мета роботи - визначення сироваткових рівнів протизапального цитокіну ІЛ-10 у хворих на хронічну хворобу нирок, що лікуються постійним діалізом ((XXH VД ст.), і їх особливостей у ГД- і ПД-пацієнтів.

Матеріали і методи. В проспективне відкрите дослідження включено 55 пацієнтів с XXН VД ст., які лікувались гемо- (ГД) і перитонеальним (ПД) діалізом протягом 2015-2019 рр.

Дослідження було проведено в два етапи. На першому визначались сироваткові рівні ІЛ-10. На другому етапі - дослідження динаміки ІЛ-10 як у ГД, так і ПД-хворих.

Дослідження вмісту ІЛ-10 в сироватці крові проводили методом імуноферментного аналізу (ELISA) за допомогою аналізатору «SunRise TouchScreen", тест-системи „Вектор Бест” (РФ). Статистична обробка результатів проведена з використанням програми "SPSS for Windows. Версія 11" і "MedStat".

Результати. Виявлено тенденцію до зниження середніх показників ІЛ-10 в крові хворих на XXН VД - 
$23,4(15,6 ; 109,4)$ порівняно з 97, $7(31,3 ; 143,2)$ пг/мл у здорових донорів (20) ( $p=0,059)$. Середній рівень цього протизапального медіатора у ПД-пацієнтів - 23,4 $(15,6 ; 70,3)$ - достовірно нижче за норму $(p=0,034)$, тоді як у ГД - тільки тенденція до зниження - 27,3 $(15,6 ; 117,2)$ пг/мл, p=0,089 порівняно з нормою. При цьому різниця середніх сироваткових рівнів ІЛ-10 при порівнянні груп хворих залежно від модальності терапії недостовірна ( $p=0,255)$.

Після лікування за допомогою еферентних методів терапії середні рівні ІЛ-10 не відрізнялись від норми як у ГД- $(p=0,199)$, так і ПД-хворих $(p=0,100)$.

Висновок. Діалізна терапія у хворих на ХХH VД супроводжується зниженням сироваткових рівнів ІЛ10 (достовірним у ПД-пацієнтів) на фоні тривалого хронічного запалення зі зниженням резервних можливостей клітин імунної системи, що його продукують.

Ключові слова: хронічна хвороба нирок УД, інтерлейкін-10, гемо- і перитонеальний діаліз.

\section{PЕЗЮME}

\section{ОСОБЕННОСТИ СЫВОРОТОЧНЫХ УРОВНЕЙ ИЛ-10 У БОЛЬНЫХ ХРОНИЧЕСКОЙ БОЛЕЗНЬЮ ПОЧЕК, КОТОРЫЕ ЛЕЧАТСЯ С ИСПОЛЬЗОВАНИЕМ ДИАЛИЗНЫХ МЕТОДОВ}

Дриянская В.Е., Дударь И.А., Шифрис И.М., Савченко В.С., Калинина Н.А., Холод В.В.

ГУ «Институт нефрологии НАМН Украины», Киев, Украина

Целью работы было определение сывороточных уровней противовоспалительного цитокина ИЛ-10 у больных с хронической болезнью почек, которые лечатся постоянным амбулаторным диализом ((ХБП VД ст.), и их особенностей у ГД- и ПД-пациентов.

Материалы и методы. В проспективное открытое исследование было включено 55 пациентов с ХБП VД ст., которые лечились гемо- (ГД) и перитонеальным (ПД) диализом на протяжении 2015-2019 гг.

Исследование было проведено в два этапа. На первом проведено определение уровней сывороточного ИЛ-10. На втором этапе - исследование динамики ИЛ-10 как у ГД, так и ПД-больных.

Определение содержания ИЛ-10 в сыворотке крови проводили методом иммуноферментного анализа (ELISA) с помощью анализатора «SunRise TouchScreen», тест-системы „Вектор Бест” (РФ). Статистическая обработка полученных результатов проведена с использованием программы "SPSS for Windows. Версия 11" и "MedStat".

Результаты. Выявлена тенденция к снижению средних показателей ИЛ-10 в крови больных ХБП УД - 23,4 (15,6; 109,4) в сравнении с 97,7 $(31,3 ; 143,2)$ пг/мл у здоровых доноров (20) ( $p=0,059)$. Средний уровень этого противовоспалительного медиатора у ПД-пациентов - 23,4 (15,6; 70,3) - достоверно ниже нормы $(p=0,034)$, тогда как у ГД - только тенденция к снижению - 27,3 (15,6; 117,2), p=0,089 по сравнению с нормой. При этом разница средних сывороточных уровней ИЛ-10 при сравнении групп больных в зависимости от модальности терапии недостоверна $(p=0,255)$.
После лечения с помощью эфферентных методов терапии средние уровни ИЛ-10 не отличались от нормы как у ГД- $(p=0,199)$, так и ПД-больных $(p=0,100)$.

Вывод. Диализная терапия у больных ХБП VД сопровождается снижением сывороточных уровней ИЛ-10 (достоверным у ПД-пациентов) на фоне длительного хронического воспаления со снижением резервных возможностей продуцирующих его клеток иммунной системы.

Ключевые слова: хроническая болезнь почек VД, интерлейкин-10, гемо- и перитонеальный диализ.

\section{SUMMARY}

\section{PECULIARITIES OF SERUM LEVELS OF IL-10 IN PATIENTS WITH CHRONIC KIDNEY DISEASE (CKD) WHO ARE TREATED USING DIALYSIS METHODS} Driianska V., Dudar I., Shifris I., Savchenko V.,
Kalinina N., Kholod V.

SI «Institute of Nephrology NAMS of Ukraine», Kyiv, Ukraine

The aim of the work was to determine the blood serum antiinflammatory cytokine IL-10 in chronic kidney disease (CKD) VD patients treated with continuous dialysis (CAPD) and their features in HD and PD patients.

Materials and methods. The prospective openlabel study included 55 patients with CKD grade VD who were treated with hemo (HD) and peritoneal (PD) dialysis during 2015-2019. The study was conducted in two stages. At the first stage, the determination of IL-10 serum level. At the second stage, a prospective study of the dynamics of IL-10 in both HD and PD patients.

Serum IL-10 level were determined by ELISA on «SunRise TouchScreen», «Vector Best» (RF). Statistical analysis was performed by using "SPSS for Windows version 11" and "MedStat".

Results. There was revealed a tendency towards a decrease in the average IL-10 values in the blood of patients with CKD VD - $23.4(15.6 ; 109.4)$ in comparison with $97.7(31.3 ; 143.2) \mathrm{pg} / \mathrm{ml}$ in healthy donors (20) $(p=0.059)$. The average level of this antiinflammatory mediator in PD-patients is $23.4(15.6 ; 70.3)$ - significantly lower than the norm $(p=0.034)$, while in HD - only a downward trend $-27.3(15.6 ; 117.2) \mathrm{pg} / \mathrm{ml}, \mathrm{p}=0.089$ in comparison with the norm. At the same time, the difference in mean serum levels of IL-10 when comparing groups of patients, depending on the modality of therapy, is insignificant $(p=0.255)$.

After treatment with efferent methods of therapy, the mean levels of IL-10 did not differ from the norm in both HD- $(p=0.199)$ and PD-patients $(p=0.100)$.

Conclusion. Dialysis therapy in patients with CKD VD is accompanied by a decrease in serum levels of IL10 (significant in PD patients) against the background of prolonged chronic inflammation with a decrease in the reserve capacity of the cells of the immune system producing it.

Key words: chronic kidney disease VD, interleukin-10, hemo- and peritoneal dialysis. 


\section{Інформація про внесок кожного учасника:}

В.Є. Дріянська - аналіз отриманих імунологічних даних і написання статті;

I. О. Дудар - контроль за лікуванням та план обстеження хворих;

I.M. Шіфріс - лікування пацієнтів та аналіз клінічних даних;

В. С. Савченко - імуноферментні дослідження ІЛ-10;

Н.А.Калініна - імуноферментні дослідження ІЛ-10;

В.В. Холод - статистичний аналіз рівнів ІЛ10 в групах хворих.

\section{ЛITEPATYPA (REFERENCES)}

1. МалышевМ.Е., БельскихО.А., СорокинаА.А., Зубор О.И. Информативность показателей цитокинового профиля сыворотки крови слюнной жидкости у больных хроническими болезнями почек . Курский научно-практический вестник «Человек и его здоровье». 2016, № 1. 44-49. https://cyberleninka. $\mathrm{ru} /$ article/n/informativnost-pokazateleytsitokinovogo-profilya-syvorotki.

2. Меленевич А.Я. Клінічне значення інтерлейкіну-18 та інтерлейкіну-10 у хворих на хронічне обструктивне захворювання легень у поєднанні з гіпертонічною хворобою. Zaporozhye medical journal. 2018. Vol. 20. №. 5. C. 623-627. http://zmj.zsmu.edu.ua.

3. Alicic R. Z., Michele T. Rooney, Katherine R. Tuttle Diabetic Kidney Disease Challenges, Progress, and Possibilities. Clin J Am Soc Nephrol. 2017. Vol. 12, N 12. P. 2032-2045. DOI: $10.2215 /$ CJN.11491116.

4. Burmeister Amanda R. and Marriott lan. The Interleukin-10 Family of Cytokines and Their Role in the CNS. Front. Cell. Neurosci. 2018. https://doi.org/10.3389/fncel.2018.00458.

5. Commins $S$. The extended IL-10 superfamily: IL-10, IL-19, IL-20, IL-22, IL-24, IL-26, IL-28, and IL-29. J. Allergy Clin Immunol. 2008. Vol.121. P. 1108-1111. DOI: $10.1016 /$ j. jaci.2008.02.026

6. Emilie $D$. Interleukin 10 in disseminated lupus erythematosus. J Soc Biol. 2002. 196 (1). P. 19-21. https://pubmed.ncbi.nlm.nih. gov/12134628.

7. Engelhardt Karin R., Grimbacher Bodo. IL-10 in humans: lessons from the gut, IL-10/IL-10 receptor deficiencies, and IL-10 polymorphisms. Curr Top Microbiol Immunol. 2014. 380. P. 1-18. DOI: 10.1007/978-3-66243492-5_1.

8. Gotoh K, Inoue M, Masaki T, et al. Obesity related chronic kidney disease is associated with spleen-derived IL-10. Nephrol Dial Transplant.
2013. 28. P. 1120-1130. DOI: 10.1093/ndt/ gfs 440 .

9. Gregorini M, Corradetti V, Rocca $C$, et al. Mesenchymal stromal cells prevent renal fibrosis in a rat model of unilateral ureteral obstruction by suppressing the renin-angiotensin system via HuR. PLoS One. 2016. 11. P. 1-19. https://doi.org/10.1371/journal. pone.0148542.

10. Hua Su, ChunTao Lei, Chun Zhang. Interleukin 6 Signaling Pathway and Its Role in Kidney Disease. Front Immunol. 2017. N 8. P 405.12. DOI: 10.3389/fimmu.2017.00405.

11. Hueso M., Navarro E., Moreso F. et al. Intragraft expression of the IL-10 gene is up-regulated in renal protocol biopsies with early interstitial fibrosis, tubular atrophy, and subclinical rejection. Am J Pathol. 2010. P. 176. 1696-1704. DOI: 10.2353/ajpath.2010.090411.

12. Jin Y, Liu R, Xie J, Xiong H, He JC, Chen N. Interleukin-10 deficiency aggravates kidney inflammation and fibrosis in the unilateral ureteral obstruction mouse model. Lab Invest. 2013. 93. P. 801-811. https://www. nature.com/articles/labinvest201364.

13. Kamanaka Masahito, Huber Samuel, Zenewicz Lauren A, Gagliani Nicola et al. Memory/effector (CD45RB(lo)) CD4 T cells are controlled directly by IL-10 and cause IL-22-dependent intestinal pathology. J Exp Med. 2011. 208 (5). P. 1027-40. DOI: 10.1084/jem.20102149.

14. Krishnamurthy $P$, Lambers $E$, Verma $S$, et al. Myocardial knockdown of mRNAstabilizing protein HuR attenuates post-MI inflammatory response and left ventricular dysfunction in IL10-null mice. FASEB J. 2010. 24. P. 2484-2494. DOI: 10.1096/fj.09149815.

15. Massimo Fioranelli and Roccia Maria Grazia. Twenty-five years of studies and trials for the therapeutic application of IL-10 immunomodulating properties. From high doses administration to low dose medicine new paradigm. J Integr Cardiol, 2014. Vol. 1 (1). P. 2-6. DOI: 10.15761/JIC. 1000102.

16. Mota A. P., Vila a S. S., das Merc S F. L., et al. Cytokines signatures in short and long-term stable renal transplanted patients. Cytokine. 2013. 62 (2). P. 302-309. DOI: 10.1016/j.cyto.2013.03.001.

17. Mu W., Ouyang X., Agarwal A. et al. IL-10 suppresses chemokines, inflammation, and fibrosis in a model of chronic renal disease. J Am Soc Nephrol. 2005. 16. P. 3651-3660. DOI: 10.1681/ASN.2005030297. 
18. Naqvi R. Glomerulonephritis Contributing to Chronic Kidney Disease. Urol. Nephrol. Open Access J. 2017. Vol. 5, N 4. P. 00179. DOI:10.15406/unoaj.2017.05.00179.

19. O’Garra A, Barrat FJ, Castro AG, Vicari A, Hawrylowicz $C$. Strategies for use of IL-10 or its antagonists in human disease. Immunol Rev. 2008. 223. P. 114-131.

20. Ouyang Wenjun, O'Garra Anne. L-10 Family Cytokines IL-10 and IL-22: from Basic Science to Clinical Translation. Immunity. 2019. 50 (4). P. 871-891. DOI: 10.1016/j.immuni.2019.03.020.

21. Rios Danyelle Romana Alves, Pinheiro Melina Barros, Wander Valadares de Oliveira Junior et al. Cytokine Signature in End-Stage Renal Disease Patients on Hemodialysis. Dis Markers. 2017. 9678391. doi: $10.1155 / 2017 / 9678391$.

22. Saraiva Margarida, Vieira Paulo, O'Garra Anne. Biology and therapeutic potential of interleukin-10. J Exp Med. 2020. 217 (1). https:// doi.org/10.1084/jem.20190418.

23. Sinuani I., Beberashvili I., Averbukh Z., Sandbank J. Role of IL-10 in the progression of kidney disease. World J Transplant. 2013. Vol 3, No 4. P. 91-98. DOI: 10.5500/ wjt.v3.i4.91.

24. Sharif M. R., Chitsazian Z., Moosavian M., et al. Immune disorders in hemodialy- sis patients. Iranian Journal of Kidney Diseases. 2015.9 (2). P. 84-96.

25. Steen Emily H., Wang Xinyi, Balaji Swathi, Butte Manish J. et al. The Role of the AntiInflammatory Cytokine Interleukin-10 in Tissue Fibrosis. Advances in Wound Care. 2020. Vol. 9, N. 4. https://doi.org/10.1089/ wound.2019.1032.

26. Stenvinkel P., Ketteler M., Johnson R.J., Lindholm B. et al. IL-10, IL-6, and TNFalpha: central factors in the altered cytokine network of uremia - the good, the bad, and the ugly. Kidney Int. 2005. Vol. 67, N 4. P. 1216-1233. DOI: 10.1111/j.15231755.2005.00200.x.

27. Sziksz E., Pap D., Lippai R. et al. Fibrosis related inflammatory mediators: role of the IL-10 cytokine family. Mediators Inflamm. 2015. 764641. https://doi. org/10.1155/2015/764641.

28. Vianna H. R., Bouissou C. M., Soares M., Tavares $M$. S. et al. Inflammation in chronic kidney disease: the role of cytokines. J. Bras. Nefrol. 2011. Vol. 33, N 3. P. 351-364. DOI: 10.1590/s0101-28002011000300012.

29. Xystrakis Emmanuel, Kusumakar Siddharth, Boswell Sandra, Peek Emma et al. Reversing the defective induction of IL-10-secreting regulatory $\mathrm{T}$ cells in glucocorticoid-resistant asthma patients. J Clin Invest. 2006. 116 (1) P. 146-55. DOI: $10.1172 / \mathrm{JCl} 21759$.

\section{АВТОРСЬКА ДОВІДКА}

\section{- Дріянська Вікторія Євгенівна \\ д.мед.н., проф., заступник директора з на- укової роботи, зав. лаб. імунології ДУ «/н- ститут нефрології НАМН України» Адреса: Київ, вул. Дегтярівська, 17-В Тел.: 0675069622 \\ E-mail: victoriadriyanskaya@gmail.com}

\section{- Дудар Ірина Олексіївна} д.мед.н., проф., зав. відділу еферентних технологій ДУ «Інститут нефрології НАМН України»

Адреса: Київ, вул. Дегтярівська 17-В Тел.: 0442259377

E-mail: directorinephrology@kiev.ua

\section{- Шіфріс Ірина Михайлівна} к.мед.н., пров. н.с. відділу еферентних технологій ДУ «Інститут нефрології НАМН України»

Адреса: Київ, вул. Дегтярівська 17-В

Тел .: 0442259377

E-mail: directorinephrology@kiev.ua

\section{- Дриянская Виктория} Евгеньевна

д.мед.н., проф., Заместитель директора по научной работе, зав. лаб. иммунологии ГУ «Институт нефрологии АМН Украины» Адрес: Киев, ул. Дегтревская, 17-В Тел: 0675069622

E-mail: victoriadriyanskaya@gmail.com

\section{- Дударь Ирина Алексеевна} д.мед.н., проф., Зав. отдела эфферентных технологий ГУ «Институт нефрологии АМН Украины»

Адрес: Киев, ул. Дегтяревская, 17-В

Тел .: 0442259377

E-mail: directorinephrology@kiev.ua

\section{- Шифрис Ирина Михайловна}

к.м.н., пер. н.с. отдела эфферентных технологий Гу «Институт нефрологии АМН Украины»

Адрес: Киев, ул. Дегтяревская 17-В

Тел.: 0442259377

E-mail: directorinephrology@kiev.ua

\section{- Driianska Viktoriia}

Doctor of Medicine, Professor, Deputy Director for Research, Head lab. of Immunology, Institute of Nephrology, National Academy of Medical Sciences of Ukraine

Address: Kyiv, str. Degtyarivska, 17-V

Tel.: 0675069622

E-mail: victoriadriyanskaya@gmail.com

\section{- Dudar Iryna}

Doctor of Medicine, Professor, Head Department of Efferent Technologies, Institute of Nephrology, National Academy of Medical Sciences of Ukraine Address: Kyiv, street Degtyarivska, 17-V Tel .: 0442259377

E-mail: directorinephrology@kiev.ua

\section{- Shifris Iryna}

Candidate of Medical Sciences, Leading Researcher of the Department of Efferent Technologies of the Institute of Nephrology of the National Academy of Medical Sciences of Ukraine Address: Kyiv, street Degtyarivska 17-V Tel.: 0442259377

E-mail: directorinephrology@kiev.ua 


\author{
- Савченко Вікторія \\ Станіславівна \\ к.б.н., с.н.с. лаб. імунології ДУ «нститут \\ нефрології НАМН України» \\ Адреса: Київ, вул. Дегтярівська, 17-В \\ Тел.: (044) 4865403 \\ E-mail: utiainew@gmail.com
}

- Калініна Наталія Альбертівна к.б.н., с.н.с. лаб. імунології ДУ «нститут нефрології НАМН України»

Адреса: Київ, вул. Депяярівська, 17-В

Тел.: (044) 4865403

E-mail: utiainew@gmail.com

\section{- Холод Валерія Володимирівна}

к.мед.н., С.н.С. лаб. імунології ДУ «Інститут нефрології НАМН України»

Адреса: Київ, вул. Дегтярівська, 17-В

Тел.: 0675069621

E-mail: valeriadriyanskaya@gmail.com

\section{- Савченко Виктория Станиславовна}

к.б.н., с.н.с. лаб. иммунологии ГУ «Институт нефрологии АМН Украины»

Адрес: Киев, ул. Дегтревская, 17-В

Тел.: (044) 4865403

E-mail: utiainew@gmail.com

- Калинина Наталья Альбертовна к.б.н., С.н.с. лаб. иммунологии ГУ «Институт нефрологии АМН Украины» Адрес: Киев, ул. Дегтяревская, 17-В

Тел.: (044) 4865403

E-mail: utiainew@gmail.com

\section{- Холод Валерия Владимировна}

к.м.н., С.н.с. лаб. иммунологии ГУ «Институт нефрологии АМН Украины» Адрес: Киев, ул. Дегтревская, 17-В Тел.: 0675069621

E-mail: valeriadriyanskaya@gmail.com

\section{- Savchenko Viktoriia}

Ph.D., senior researcher lab. of Immunology, Institute of Nephrology, National Academy of Medical Sciences of Ukraine

Address: Kyiv, str. Degtyarivska, 17-V

Tel.: (044) 4865403

E-mail: utiainew@gmail.com

\section{Kalinina Nataliia}

Ph.D., senior researcher lab. of Immunology, Institute of Nephrology, National Academy of Medical Sciences of Ukraine

Address: Kyiv, str. Degtyarivska, 17-V

Tel.: (044) 4865403

E-mail: utiainew@gmail.com

\section{- Kholod Valeriia}

Candidate of Medical Sciences, Senior Research Fellow lab. of Immunology, Institute of Nephrology, National Academy of Medical Sciences of Ukraine

Address: Kyiv, street Degtyarivska, 17-V

Tel.: 0675069621

E-mail: valeriadriyanskaya@gmail.com

Стаття надійшла до редакції 27.03.2021 p. 